\title{
Subclinical cardiac abnormalities and physical function in asymptomatic elderly
}

\author{
Angela S Koh ${ }^{1,2^{*}}$, Feiqiong Huang ${ }^{1}$, Thu Thao Le ${ }^{1}$, Jia ing Wong ${ }^{1}$, Ru San Tan ${ }^{1,2}$, Serene Chua ${ }^{1}$, Yi Ying Han ${ }^{1}$, \\ Stuart Cook ${ }^{1,2}$, Woon Puay Koh ${ }^{2}$ \\ From 19th Annual SCMR Scientific Sessions \\ Los Angeles, CA, USA. 27-30 January 2016
}

\section{Background}

While it is known that the heart remodels progressively with age, data characterizing the relationship between cardiac remodelling and function on physical function among the aged are limited.

\section{Aim}

We investigated the association between left ventricular (LV) concentricity and LV function with handgrip strength (shown to correlate with mortality in the elderly) and timed-up-and-go test (for lower extremity function) among clinically asymptomatic elderly.

\section{Methods}

In this community-based cohort of 28 patients free of known cardiac disease (mean age $73.8 \pm 4$ ) with preserved LV ejection fraction (mean LVEF $69.8 \pm 6.4$ ) and cardiac index (mean $3.1 \pm 0.57$ ), we assessed cardiac remodelling by cardiac MRI (concentricity ${ }^{0.67}$ (mass/ end-diastolic volume ${ }^{0.67}$ ) and LV function by resting tissue Doppler imaging (TDI) performed at the septal and lateral mitral annulus, deriving myocardial systolic velocity (S), diastolic velocity (E) and ratio of E/A.

\section{Results}

There were significant correlations between handgrip and LV concentricity $(\mathrm{r}=0.49, \mathrm{p}=0.008)$, lateral $\mathrm{S}(\mathrm{r}=$ $0.45, \mathrm{p}=0.041)$, septal A $(\mathrm{r}=0.45, \mathrm{p}=0.04)$, and between timed-up-and-go and LV concentricity $(\mathrm{r}=$ $0.47, \mathrm{p}=0.013)$, lateral $\mathrm{E} / \mathrm{A}(\mathrm{r}=-0.49, \mathrm{p}=0.023)$, septal A $(r=0.45, p=0.043)$. By regression analysis, LV concentricity $(\beta=0.071,95 \% \mathrm{CI} 0.011-0.132, \mathrm{p}=0.023$ ) (with adjustment for systolic blood pressure) and lateral E/A

${ }^{1}$ Cardiology, National Heart Centre Singapore, Singapore, Singapore Full list of author information is available at the end of the article $(\beta=-0.15,95 \% \mathrm{CI}-0.29-0.009, \mathrm{p}=0.039)$ were independently predictive of handgrip strength and timed-upand-go respectively.

\section{Conclusions}

These preliminary observations provide important insights into a possible link between subclinical alterations in cardiac structure and function and physical function, further study is required to clarify these findings with a view to preserve health and function amongst the elderly.

\section{Authors' details}

${ }^{1}$ Cardiology, National Heart Centre Singapore, Singapore, Singapore. ${ }^{2}$ DukeNUS Graduate Medical School, Singapore, Singapore.

Published: 27 January 2016

doi:10.1186/1532-429X-18-S1-P146

Cite this article as: Koh et al:: Subclinical cardiac abnormalities and physical function in asymptomatic elderly. Journal of Cardiovascular Magnetic Resonance 2016 18(Suppl 1):P146.

Submit your next manuscript to BioMed Central and take full advantage of:

- Convenient online submission

- Thorough peer review

- No space constraints or color figure charges

- Immediate publication on acceptance

- Inclusion in PubMed, CAS, Scopus and Google Scholar

- Research which is freely available for redistribution 